\title{
Physical Map
}

National Human Genome Research Institute (NHGRI)

\section{Source}

National Human Genome Research Institute (NHGRI). Physical Map.

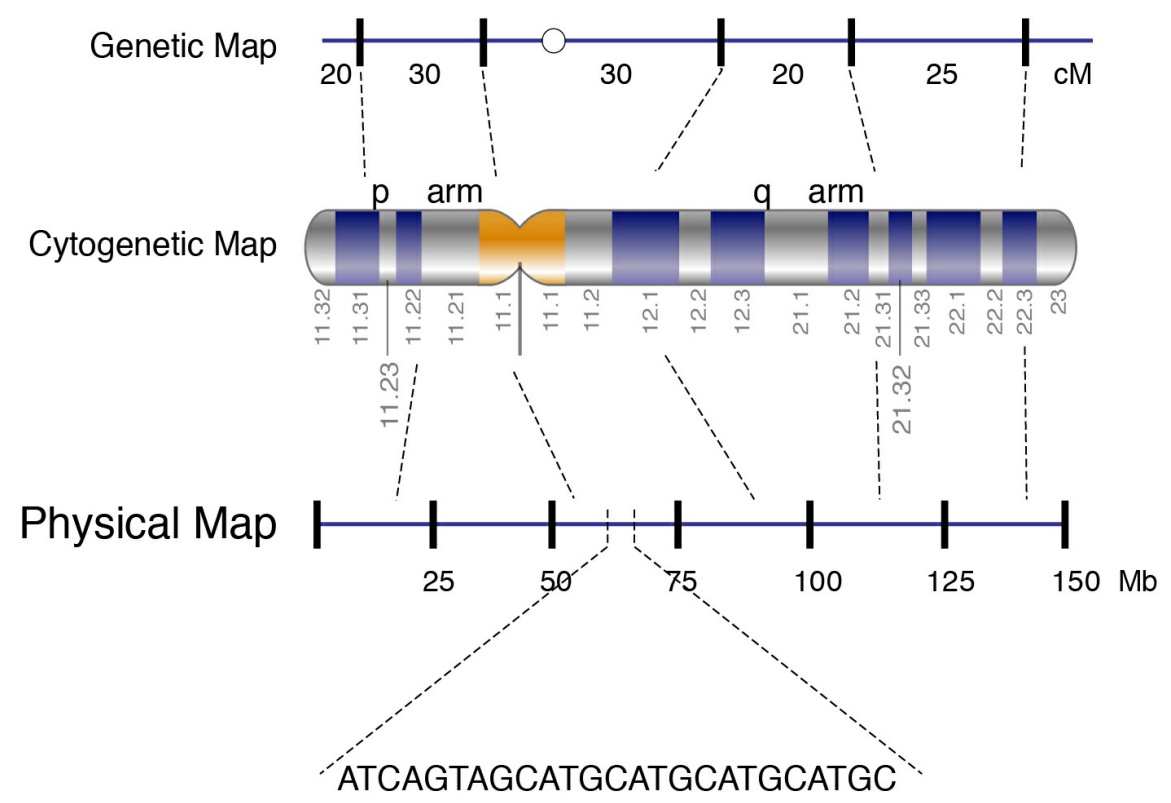

A physical map of a chromosome or a genome that shows the physical locations of genes and other DNA sequences of interest. Physical maps are used to help scientists identify and isolate genes by positional cloning. 